\title{
Heat damage in sclerophylls is influenced by their leaf properties and plant environment ${ }^{1}$
}

\author{
Philip K. GROOM², Department of Environmental Biology, Curtin University of Technology, P.O. Box U1987, Perth, \\ Western Australia 6845, Australia, and Centre for Horticulture and Plant Sciences, University of Western Sydney, \\ Hawkesbury Campus, Locked Bag 1797, Penrith South DC, New South Wales 1797, Australia, \\ e-mail: p.groom@uws.edu.au \\ Byron B. LAMONT, Sylvia LEIGHTON, Pattie LEIGHTON \& Chantal BURROWS, Department of \\ Environmental Biology, Curtin University of Technology, P.O. Box U1987, Perth, Western Australia 6845, Australia.
}

\begin{abstract}
Mediterranean southwestern Australia experienced two successive days of extreme $\left(>45^{\circ} \mathrm{C}\right)$ maximum temperatures and hot winds during the summer of 1991, resulting in adult mortality and extensive crown damage in a sclerophyllous mallee-heathland. To investigate the relationship between leaf attributes, plant environment, and heat tolerance in sclerophylls, measurements of plant height, leaf clustering, leaf morphology (thickness, dry density, area, perimeter/area ratio), percentage crown damage, and percentage mortality, and categories of exposure to wind, shade, and bare soils were recorded for 40 heat-damaged and 14 undamaged co-occurring species. Analyzing the entire dataset by principal components analysis showed that undamaged species had thicker leaves (on average $61 \%$ thicker) than species with damaged leaves and were more exposed to wind, sun, and bare soil. Thicker leaves are a common response to hot, dry, and more exposed environments and are more heat tolerant than thinner leaves. A separate analysis of the Proteaceae (25 damaged and six undamaged species) showed a similar trend to the overall dataset. An analysis of the Myrtaceae (10 damaged and three undamaged species) showed that wind exposure and level of shading were the most important variables influencing the degree of leaf damage. Percentage leaf damage was significantly correlated with percentage adult mortality, but not with the ability of a species to regrow (percentage of plants producing new shoots). Differences between undamaged and damaged species may be a result of preconditioning, whereby species growing in more exposed habitats were pre-adapted to tolerate periods of heat stress. It is unlikely that the study species were able to reduce leaf temperatures via transpirational cooling during the hottest part of the 2-d heatwave. The ability of a species to tolerate extreme temperature events will be determined by the interaction between leaf heat loads, leaf heat-storing capacity, and the degree of exposure to environmental elements.
\end{abstract}

Keywords: heat tolerance, leaf clustering, leaf damage, leaf thickness, Mediterranean-type summer.

Résumé : Le sud-ouest de l'Australie, une région au climat méditerranéen, a connu deux journées successives de températures maximales extrêmes $\left(>45^{\circ} \mathrm{C}\right)$ et de vents chauds pendant l'été 1991 , ce qui a eu pour effet d'engendrer une mortalité chez les arbres adultes ou de causer des dommages considérables à la couronne de ces derniers dans les landes à plantes sclérophylles. Afin de connaître les relations existant entre les caractéristiques des feuilles, l'environnement des plantes et la tolérance à la chaleur des plantes sclérophylles, nous avons mesuré différents paramètres chez 40 espèces ayant subi des dommages causés par la chaleur et chez 14 autres espèces voisines n'ayant pas été affectées. Les paramètres retenus ont été la hauteur des plantes, le regroupement des feuilles, la morphologie des feuilles (épaisseur, densité à l'état sec, surface, rapport du périmètre sur la surface), le pourcentage de dommages à la couronne, le pourcentage de mortalité, ainsi que diverses catégories d'exposition au vent, d'ombrage et de sol dénudé. L'analyse en composantes principales de toutes les données montre que les espèces non affectées possèdent des feuilles plus épaisses (61 \% plus épaisses en moyenne) que les espèces dont le feuillage a subi des dommages. Elles sont également plus exposées au vent, au soleil et à l'absence de végétation au sol. On trouve d'ailleurs fréquemment chez les plantes des environnements chauds, secs et exposés des feuilles plus épaisses. On obtient des résultats similaires lorsqu'on examine de façon plus particulière la famille des Proteaceae, qui comprend 25 espèces affectées et six non affectées. Chez les Myrtaceae (10 espèces affectées et trois non affectées), l'analyse montre que l'exposition au vent et le niveau d'ombrage sont les principales variables influençant le degré de dommages aux feuilles. Le pourcentage de dommages aux feuilles est corrélé de façon significative avec le pourcentage de mortalité chez les adultes, mais il ne l'est pas avec l'habileté de l'espèce à se régénérer, c'est-à-dire avec le pourcentage de plantes produisant de nouvelles pousses. Les différences observées entre les espèces affectées et celles qui ne l'ont pas été pourraient provenir d'une forme de conditionnement chez les plantes : les espèces qui croissent dans des habitats plus exposés toléreraient davantage des périodes de haute température. Il est peu probable que les espèces étudiées aient été capables de réduire la température de leurs feuilles par transpiration lors des périodes les plus chaudes des deux journées de chaleur intense. L'habileté d'une espèce à tolérer des épisodes de température extrême est déterminée par l'interaction entre la chaleur emmagasinée dans les feuilles, sa capacité à emmagasiner de la chaleur et son degré d'exposition aux éléments naturels.

Mots-clés : dommages aux feuilles, épaisseur des feuilles, été de climat méditerranéen, regroupement des feuilles, tolérance à la chaleur.

Nomenclature: Paczkowska \& Chapman, 2000.

${ }^{1}$ Rec. 2003-06-23; acc. 2003-09-22.

Associate Editor: Josep Escarré.

${ }^{2}$ Author for correspondence. 
ÉCOSCIENCE, VoL. 11 (1), 2004

\section{Introduction}

Convergence of sclerophyllous leaf traits between the world's Mediterranean-type ecosystems reflects the hot, dry summers typical of these areas (Cody \& Mooney, 1978; Lamont, Groom \& Cowling, 2002), where maximum summer temperatures are often $>40{ }^{\circ} \mathrm{C}$ (Nahal, 1981). This convergence is usually attributed to reducing tissue desiccation while maximizing water-use efficiencies in drought-prone environments (Mooney \& Dunn, 1970; Cody \& Mooney, 1978; Oertli, Lips \& Agami, 1990), although sclerophylly is also an ultimate response to nutrient-poor soils and herbivory (Turner, 1994). Leaves are typically (but not always) small and thick, as there is the necessity to avoid excessive leaf heat loads, high light intensities, and leaf water loss during the summer period (Valladares \& Pearcy, 1997).

Although there is no evidence to suggest that sclerophylly by itself is an adaptation to tolerate high summer temperatures, leaf mass per area (an index of sclerophylly) is known to affect leaf heat capacity and rates of change in leaf temperature (Jones, 1992). Variations in leaf temperature at different times of the day have been related to differences in leaf mass per area, leaf thickness, and leaf volume (Hegazy \& El Amry, 1998). The temperature optimum for photosynthesis is species specific (Gratani et al., 2000; Larcher, 2000) and can be quite variable for co-occurring species (Oechel et al., 1981; Larcher, 2000). Thus, not all species demonstrate the same degree of leaf damage when subjected to a given period of heat stress (MacBryde et al., 1971).

There is limited information on the heat tolerance of sclerophyllous shrublands and woodlands in Mediterraneantype ecosystems. This is partly because it is difficult to identify the effects of extreme heat in the field, since a combination of factors may contribute to observed injury (Pereira \& Chaves, 1995). The effects of extreme summer stress have been well documented for Mediterranean ecosystems at the species and community level. For periods of prolonged water stress, drought tolerance is considered an extension of the normal summer response (Hobbs \& Mooney, 1995; Peñuelas, Lloret \& Montoya, 2001). In contrast, extreme temperature events (daily maximum temperature $>40{ }^{\circ} \mathrm{C}$ ) may last no more than a few days; temperatures capable of causing leaf damage will only occur for a few hours each day (Larcher, 2000).

Mediterranean southwestern Australia experienced successive days of extreme $\left(>40{ }^{\circ} \mathrm{C}\right)$ temperatures and hot winds in January/February 1991, contributing to the death of native perennial shrub and tree species in a mallee-heathland (this paper) and a Banksia woodland (Groom, Froend \& Mattiske, 2000). The latter resulted from a combination of severe drought stress and high temperatures. In the mallee-heathland, leaf damage and plant mortality were observed after two consecutive days of maximum temperatures $>45{ }^{\circ} \mathrm{C}$. The level of leaf damage and mortality varied between species, as did leaf morphology and degree of exposure to the elements. This paper explores whether leaf heat damage in 54 co-occurring sclerophyllous species can be explained in terms of their leaf morphology, leaf clustering, and local environmental conditions (exposure to wind, shade, and unshaded soils).

\section{Methods}

\section{STUDY SITE}

Three sites were examined in an area within and surrounding Mettler Lake Nature Reserve ( $34^{\circ} 34^{\prime} \mathrm{s}, 118^{\circ} 35^{\prime} \mathrm{E}$ ), $81 \mathrm{~km}$ northeast of Albany, southwestern Australia. Sites were $2 \mathrm{~km}$ from each other, occurring on well drained, deep sandy soils or sandy loam soils near creeks and swamps, and similar in species composition. Beard (1972) described the area as a mallee-heath dominated by shrub species in the Proteaceae and Myrtaceae with patches of Eucalyptus marginata and E. occidentalis trees. Long-term weather records (1966-1997, Mettler weather station) show that this area experiences a moderate Mediterranean-type climate (3-4 dry months; Beard, 1984). Winters (MayAugust) are cool and wet, with a mean minimum temperature of $7{ }^{\circ} \mathrm{C}$ and a mean rainfall of $278 \mathrm{~mm}$. Summers (December-March) are hot, with mean highest monthly temperature of $36{ }^{\circ} \mathrm{C}$ and a mean rainfall of $118 \mathrm{~mm}$. The annual mean rainfall is $610 \mathrm{~mm}$. Mettler weather station is $2-4 \mathrm{~km}$ from the study sites. A mini-heatwave $\left(>45^{\circ} \mathrm{C}\right)$ occurred over two consecutive days (31 January and 1 February 1991), and it was several days afterwards that leaf damage and plant mortality were first observed in the native vegetation at the three sites.

\section{FIELD SURVEY}

Surveys of the extent of leaf damage (of total leaf area), plant mortality, and regrowth were undertaken between May and July 1991. Data were collected from 40 native species that were noted to have been affected, based on observations of leaf discoloration (orange to brown) in the days after the heatwave. Fourteen undamaged species were chosen to reflect a range of leaf shape and sizes. Fifty plants per species, selected randomly from all three sites, were examined for the heat-damaged species; 25 plants were examined for the undamaged species. Plants that had recently died were assumed to have been killed as a result of the heatwave, although we cannot dismiss the possibility that the high temperatures caused shoot death in some species that then allowed canker disease (Botryosphaeria ribis and Cryptodiaporthe melanocraspeda; Shearer, Fairman \& Bathgate, 1995) invasion, leading to additional cases of damage and death not caused by high temperatures alone. None of the damaged species possessed discoloured leaves prior to the heatwave. Plants were identified to species level with nomenclature following that of Paczkowska and Chapman (2000); these species are listed in Table I.

For each plant, percentage leaf damage was allocated to seven categories, based on the proportion of leaves showing signs of leaf discoloration: (0) $0 \%$, (1) $1-14 \%$, (2) $15-$ $24 \%$, (3) $25-49 \%$, (4) $50-74 \%$, (5) $75-99 \%$, and (6) $100 \%$. Leaf damage was assessed in terms of leaf discoloration, from green undamaged leaves to damaged leaves that were orange/brown. In addition, height of each plant was estimated and assigned to one of six height classes: a) 0-0.49 m, b) $0.50-0.99 \mathrm{~m}, \mathrm{c}) 1.00-2.49 \mathrm{~m}$, d) $2.5-4.99 \mathrm{~m}$, e) $5.0-10.00 \mathrm{~m}$, and f) $>10.00 \mathrm{~m}$. Regenerative response to disturbance (typically fire) for each species was also assessed as either (1) resprouter (mature plant regrows 
after disturbance) or (2) nonsprouter (mature plant killed by disturbance).

Exposure to wind, exposure of soil, and level of shading of individual plants were assessed subjectively by classifying each plant to one of four exposure classes. For exposure to wind and mineral soil, exposure for each plant was ranked as (1) none, (2) low, (3) moderate, or (4) high exposure, based on their level of protection (wind exposure) or soil shading (soil exposure) by surrounding plants. Levels of shading for each plant were subjectively ranked as (1) in full sun, (2) moderate sun, (3) moderate shade, or (4) full shade. Assessments of exposure were routinely conducted between 1000 and 1500 local time in conjunction with assessments of leaf damage and regrowth.

\section{LEAF ATTRIBUTES}

Five branches representing the previous year's growth were collected from five plants per species. From each branch two fully expanded leaves were removed, and the area and perimeter (without the petiole) of each leaf was measured using a digital image analyser (DIAS-II, Delta T-Devices, Cambridge, United Kingdom). Leaf thickness was measured mid-leaf with vernier calipers, and dry mass was recorded after drying in a $70{ }^{\circ} \mathrm{C}$ oven for $48 \mathrm{~h}$. Dry leaf density for each leaf was then calculated as mass/(area $\times$ thickness) (Witkowski \& Lamont, 1991). Correcting for shape, dry leaf density was calculated as mass $/(\pi / 4 \times$ area $\times$ thickness) (Witkowski \& Lamont, 1991) for needle-leaved species (e.g., Hakea sulcata). A $10-\mathrm{cm}$ segment was removed from each branch, and the total number of leaves on the segment was counted. For Allocasuarina, individual green branchlets were treated as if they were leaves. The number of leaves per $10-\mathrm{cm}$ branch segment was estimated for the grasstree species Kingia australis based on the expected position of the stem (stem surrounded by leafbases; sensu Korczynskyj, 2002).

\section{DATA ANALYSES}

Principal components analyses were conducted using SYN-TAX (Podani, 1995), with leaf attributes and environmental factors as variables. Weighted means were calculated for variables for which data were collected on an ordinal scale. Leaf area and leaf number per branch segment were log transformed, and height and perimeter/area were square-root transformed to improve their linearity relative to the other variables. For leaf damage data, 0 was converted to 10 and then everything was square rooted; for mortality data, 0 was converted to 1 and everything was logged. Differences in leaf properties and plant environment attributes of undamaged and damaged species were analyzed using $t$-tests. Paired $t$-tests were used for pairwise comparisons. Homogeneity of variances was checked by residual plots and transformed as necessary by log or square roots, with data presented as untransformed means.

\section{Results}

\section{Climate}

The heatwave experienced on 31 January and 1 February 1991 produced maximum temperatures of $45.5^{\circ} \mathrm{C}$ and
$47.0{ }^{\circ} \mathrm{C}$ respectively, the highest temperatures measured at the Mettler weather station since recordings began in 1966 . Both days were relatively dry $(15 \%$ and $5 \%$ relative humidity recorded at 1500) with a wind speed of $9 \mathrm{~km} \cdot \mathrm{h}^{-1}$ in the morning (0900) and $16 \mathrm{~km} \cdot \mathrm{h}^{-1}$ in the afternoon (1500). No rain was recorded on either day. The previous rain event occurred on 23 January $(0.4 \mathrm{~mm})$. Total rainfall received in January 1991 was $8.6 \mathrm{~mm}$, compared with the long-term mean of $26.4 \mathrm{~mm}$. Mean maximum temperature was $25.1{ }^{\circ} \mathrm{C}$ for January 1991 and $26.5{ }^{\circ} \mathrm{C}$ for February 1991. January and February experienced $5 \mathrm{~d}$ and $6 \mathrm{~d}$, respectively, with a maximum temperature $\geq 30^{\circ} \mathrm{C}$. The highest temperatures recorded in the following months were $33.0^{\circ} \mathrm{C}$ (March) and $33.5^{\circ} \mathrm{C}$ (April).

\section{FIELD STUDY}

A survey of the native flowering plant communities, including sedges and rushes (three species), occurring at the three study sites showed that $59-73 \%$ of species present displayed signs of leaf damage 3 months after the heatwave. The 54 species examined were dominated by species in the Proteaceae (31 species, 25 displaying signs of leaf damage) and Myrtaceae (13 species, 10 displaying signs of leaf damage). Percentage leaf damage ranged from $0-89 \%$ of crown (Table I) and was significantly correlated with adult mortality $(0-44 \% ; r=0.82, P<0.001)$, although the two species with the highest level of damage (Dasypogon bromeliifolius and Eucalyptus decurva) had only $6.0 \%$ and $30.0 \%$ plant mortality, respectively. A species' ability to recover from heat damage, measured as the percentage of plants producing new shoots, was not significantly correlated with the amount of damage sustained $(r=-0.22$, $P>0.05)$.

Thirty-one species were classified as resprouters, including 12 species that showed no symptoms of leaf heat damage (Table I). There was no significant difference in the recovery of damaged plants (nonsprouters: $58.0 \pm 38.8 \%$; resprouters: $76.2 \pm 30.8 \%$; mean $\pm \mathrm{SD}$ ) or the level of mortality (nonsprouters: $21.0 \pm 9.2 \%$; resprouters: $10.2 \pm 10.6 \%$ ) between regenerative strategies $(P>0.05 ; t$-test $)$.

\section{LEAF AND ENVIRONMENTAL ATTRIBUTES}

For the 54 species, leaf area varied from $3 \mathrm{~mm}^{2}$ (Beaufortia micrantha) to $6,916 \mathrm{~mm}^{2}$ (Banksia repens), and leaf thickness from $0.13 \mathrm{~mm}$ (Beaufortia anisandra) to $2.28 \mathrm{~mm}$ (Kingia australis; Table I), with no significant correlation between leaf area and thickness $(r=0.09, P>0.05)$. Overall, species with small leaf areas possessed more leaves per branch segment $(r=-0.45$ for logged data, $P<0.05)$ and larger perimeter/area $(r=0.54$ for square-root data, $P<0.05)$. Leaf dry density was negatively correlated with leaf thickness $(r=-0.39, P<0.05)$. Height was significantly negatively correlated with leaf clustering, i.e., leaves per branch $(r=-0.41, P<0.05)$, but not leaf area.

Analyzing the entire dataset by principal components analysis (PCA; Figure 1) showed that the 14 undamaged species had thicker leaves and were more exposed to wind, sunlight, and bare soils. Significant differences in leaf thickness between undamaged and damaged species were confirmed by a $t$-test $(P=0.0131)$. Undamaged leaves were 


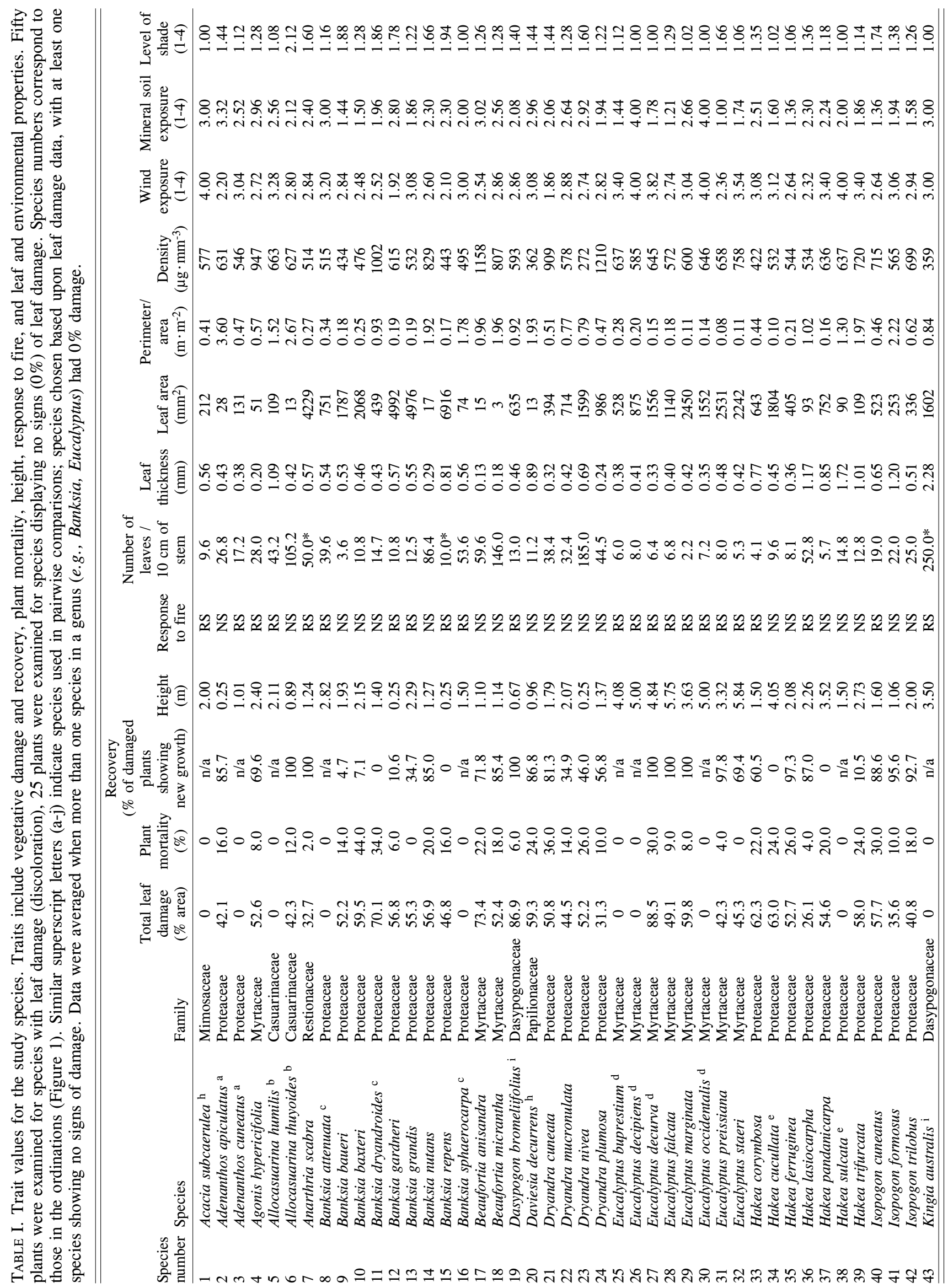




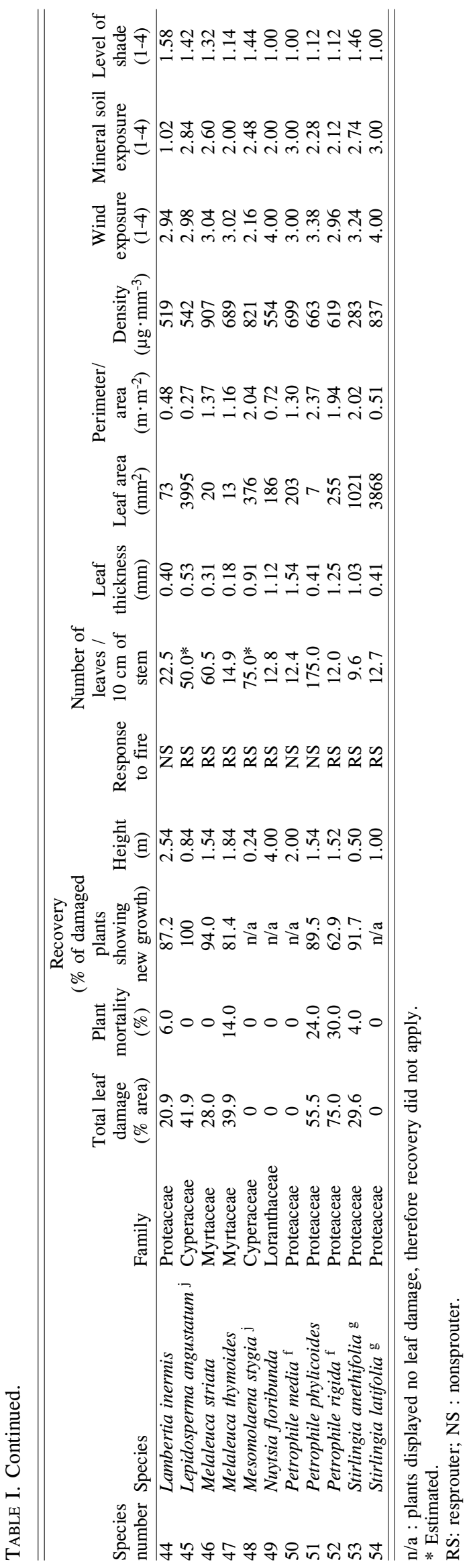

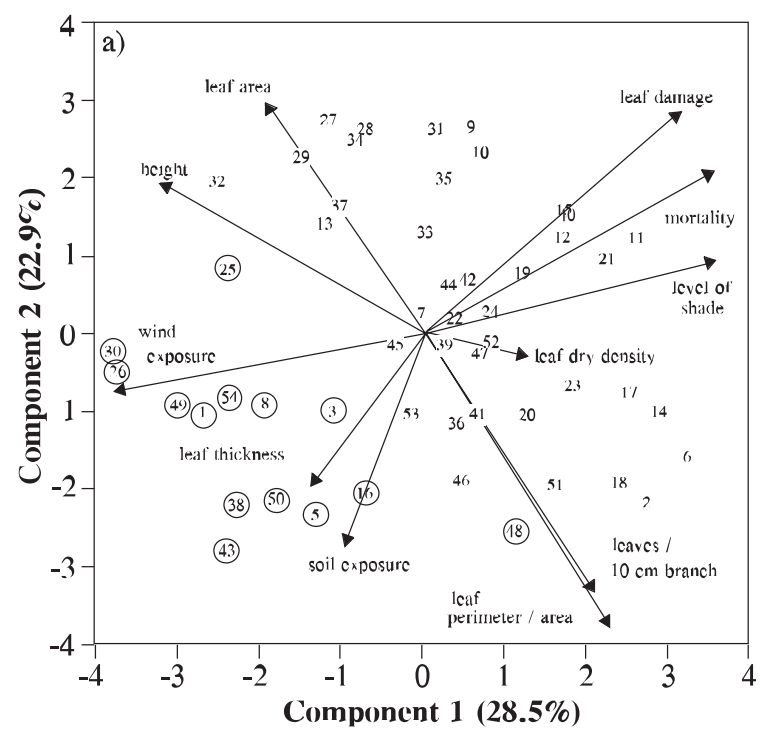
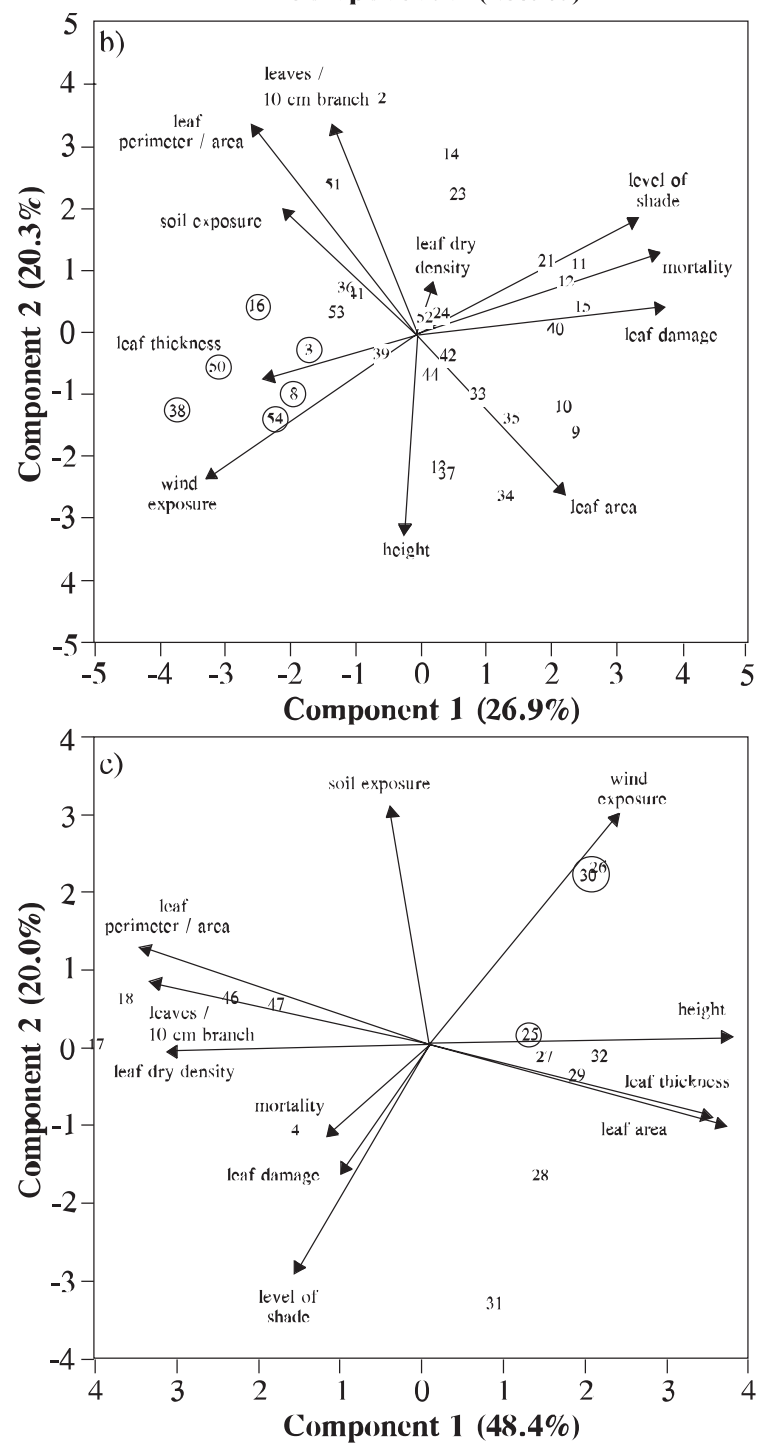

FIGURE 1. Principal components analysis of a) all 54 species, b) Proteaceae species, and c) Myrtaceae species. Numbers represent species listed in Table I. Circled numbers represent species that displayed no crown damage. Vectors indicate direction and strength of leaf and environmental variables. 
more sclerophyllous (leaf mass per area $=516 \pm 323 \mathrm{~g} \cdot \mathrm{m}^{-2}$ ) than damaged leaves $\left(319 \pm 153 \mathrm{~g} \cdot \mathrm{m}^{-2}, P=0.0106\right)$, although this was due to their greater thickness. A negative correlation existed between the levels of wind exposure and shade $(r=-0.64, P<0.05)$, but there was no correlation with soil exposure. Percentage canopy damage and plant mortality were negatively correlated with wind $(r=-0.40)$ and soil $(r=-0.31)$ exposure and positively correlated with level of shading $(r=0.38)$.

A PCA analysis of the 31 Proteaceae species showed trends similar to those in the overall dataset (Figure 1b): the six undamaged species were more likely to have thicker leaves and be more exposed to wind and bare soils. In contrast, a PCA analysis of the 13 Myrtaceae species (Figure 1c) showed that wind exposure and, hence, level of shading were the most important variables influencing the degree of leaf damage, although none was significantly correlated. For myrtaceous species, no leaf attribute was significantly correlated with percentage leaf damage.

A comparison of leaf traits and environmental exposures was conducted on 10 species pairs (pairings given in Table I). Pairings were selected at the genus, family, or order level to investigate cross-species relationships, with each pair including species with minimum $(0 \%$ damage) and maximum percentage damage. Seven of the species pairs had larger leaf thickness in undamaged species, but there was no significant difference between the two damage types (Table II). Five of the species pairs had larger leaf areas, but again there was no significant difference between the two damage types (Table II). Overall, there were no significant differences between the two damage types for other aspects of their leaf morphology. Paired $t$-tests showed significant differences in their levels of shading (Table II). Nine of the species pairs displayed greater levels of soil exposure in undamaged plants, but there was no significant difference (Table II).

\section{Discussion}

It was expected that leaf heat damage would be related to leaf area or the perimeter-area ratio because of the relationship between leaf size and boundary layer resistance (Gates, 1968; Givnish, 1978). Our work shows that of the five biological attributes measured, the main difference between heat-damaged and undamaged species was leaf thickness, with undamaged leaves on average $61 \%$ thicker than damaged leaves. Nevertheless, species with the highest percentage leaf damage were not necessarily those with the thinnest leaves (e.g., Eucalyptus decurva). This may have been confounded by the occurrence of both broad- and needle-leaved (e.g., Hakea sulcata, H. trifurcata) species at the study sites. For needle leaves, leaf thickness is equivalent to leaf width, which directly affects leaf area (area $\approx$ length $\times$ thickness) and thus has implications for leaf gas and heat exchange properties (Nobel, 1988). For broad leaves, leaf thickness is independent of leaf area and hence convective heat transfer (Givnish, 1978). Between species, an increase in leaf thickness has been associated with increased photosynthetic capacity (Niinemets, 1999; Roderick, Berry \& Noble, 2000), long-term water-use efficiency (Hanba, Miyazawa
TABLE II. Mean $( \pm$ SD) leaf attributes and exposure rankings of 10 species pairs. Species were paired according to taxonomic similarity and level of canopy damage (see pairings in Table I).

\begin{tabular}{lccc}
\hline \hline & \multicolumn{2}{c}{ Level of damage } & \\
& $\begin{array}{c}\text { High } \\
(59.8 \pm 20.4 \%)\end{array}$ & $\begin{array}{c}\text { None } \\
(0 \%)\end{array}$ & $\begin{array}{c}P \\
\text { (paired } t \text {-test) }\end{array}$ \\
\hline Height $(\mathrm{m})$ & $1.6 \pm 1.6$ & $2.0 \pm 1.3$ & 0.2298 \\
Number of leaves / & & & \\
$\quad 10$-cm stem & $25.8 \pm 30.7$ & $48.9 \pm 74.0$ & 0.2756 \\
Area $\left(\mathrm{mm}^{2}\right)$ & $976 \pm 1239$ & $799 \pm 1181$ & 0.6670 \\
Perimeter/area $\left(\mathrm{m} \cdot \mathrm{m}^{-2}\right)$ & $1.5 \pm 1.2$ & $1.0 \pm 0.6$ & 0.4984 \\
Thickness $(\mathrm{mm})$ & $0.62 \pm 0.32$ & $0.98 \pm 0.66$ & 0.1690 \\
Dry density $\left(\mu \mathrm{g} \cdot \mathrm{mm}^{-3}\right)$ & $584 \pm 191$ & $627 \pm 143$ & 0.6465 \\
Wind exposure & $3.0 \pm 0.4$ & $3.3 \pm 0.6$ & 0.0560 \\
Soil exposure & $2.4 \pm 0.6$ & $2.7 \pm 0.4$ & 0.0989 \\
Level of shade & $1.4 \pm 0.4$ & $1.1 \pm 0.1$ & 0.0120 \\
\hline \hline
\end{tabular}

\& Terashima, 1999), and greater costs for construction per unit surface area (Niinemets, 2001). The production of small, clustered leaves may also be viewed as a tradeoff between maximizing photosynthetic capacity (total area) and minimizing construction costs and leaf heat loads (Miller, 1983).

Species tend to be thick-leaved in hot, dry, more exposed environments, as thick leaves lose less water per unit volume than do thin leaves of the same stomatal resistance and effective leaf size (Givnish, 1978). Differences between undamaged and damaged species reported in our paper may be a result of preconditioning (Kappen, 1981), whereby species growing in more exposed habitats (e.g., growing in high light, unshaded soil) are pre-adapted to tolerate periods of sustained heat stress. Bragg and Westoby (2002) noted that for a given height, species with smaller leaves occurred in stronger light, while large-leaved species occurred in weaker light, and explained this dichotomy in terms of leaf heat loads. The reverse relationship occurs for leaf thickness (Vogel, 1968; Smith \& Nobel, 1978; Valladares \& Pearcy, 1999), as the capacity to absorb heat increases with leaf thickness (Larcher, 2000; Terashima, Miyazawa \& Hanba, 2001). As leaves thicken, water tends to replace air spaces and dry matter per volume (Roderick et al., 1999), increasing their thermal capacity (Jones, 1992). Thus, within the mallee-heathland, thicker-leaved species were more heat tolerant than thin-leaved species, enabling them to cope with higher thermal loads.

Plants grown in the sun are typically thicker-leaved than plants growing in the shade (Yun \& Taylor, 1986; Smith, Bell \& Shepherd, 1998; Terashima, Miyazawa \& Hanba, 2001) and, depending on other growing conditions, may or may not display differences in transpiration rates (Yun \& Taylor, 1986). Under non-drought, high-temperature $\left(38-44{ }^{\circ} \mathrm{C}\right)$, and full-sun conditions, leaf temperatures of the sclerophyll shrub Heteromeles arbutifolia were lower than air temperature for sun-grown plants and greater than air temperature for plants growing in the shade (Valladares \& Pearcy, 1997), with the lower leaf temperatures in sun-grown plants attributed to transpirational leaf cooling. At a maximum air temperature of $45-47^{\circ} \mathrm{C}$, it is unlikely that species within the mallee-heathland had open stomata, especially during the hottest part of the two 
days. In other studies, diurnal stomatal conductance often has remained $<0.03 \mathrm{~mol} \cdot \mathrm{m}^{-2} \cdot \mathrm{s}^{-1}$ in response to the temperature and water-stress conditions of a Mediterranean-type summer (Lange, Tenhunen \& Braun, 1982; Valladares \& Pearcy, 1997; Faria et al., 1998), resulting in up to a $10^{\circ} \mathrm{C}$ increase in leaf temperature. In our study, similar increases would have resulted in leaves heating beyond lethal levels, assuming they are similar to those of other Mediterranean environs (i.e., $47-50{ }^{\circ} \mathrm{C}$; Larcher, 2000).

Floristically, our study sites were dominated by species in the Proteaceae (57\%) and Myrtaceae (24\%). Leaf-environment relationships within the Proteaceae were similar to that of the entire dataset, with percentage leaf damage associated with a decrease in leaf thickness. For the Myrtaceae, percentage leaf damage was not associated with any leaf attribute, but was related to degree of wind exposure. The different relationships between the two families may be due to the Myrtaceae consisting of eight overstorey Eucalyptus species that were larger, thicker leaved, and generally more exposed than the five understorey species. This was further confounded by the fact that three of the Eucalyptus species showed no damage, while one species recorded the highest level of damage $(88.5 \%)$. One of the undamaged species (E. occidentalis) is known to tolerate air temperatures up to $51^{\circ} \mathrm{C}$, with total leaf death occurring at $55^{\circ} \mathrm{C}$ (Zohar, Waisel \& Karschon, 1981). In contrast, three of the nine Banksia (Proteaceae) species occurred in the overstorey, with only one of these $(B$. attenuata) showing no signs of heat damage. Despite these relationships with leaf damage as identified by principal components analysis, there was no significant difference between species pairs chosen to represent contrasting levels of damage, other than that at the environmental level.

The relationships between heat stress and other environmental factors can be complex. Leaf discoloration caused by heat stress results from the detrimental effect of high leaf heat loads on the chloroplasts, resulting in a depression of photosynthesis and cell death (Berry \& Björkman, 1980). Leaf discoloration in southwestern Australian sclerophylls can also occur in response to prolonged summer drought, but unlike discoloration due to heat damage, it reverts to its pre-drought colour after 10$15 \mathrm{~mm}$ of rain (George, 2002). In our study we considered that the level of leaf discoloration observed was not primarily a function of water stress, as the leaves did not regreen in response to rainfall. However, we cannot dismiss the possibility that the extent of heat damage observed resulted from a combination of summer drought and high air temperatures (Groom, Froend \& Mattiske, 2000). For sclerophylls in Mediterranean-type environments, surviving the hot, dry summers requires structural and physiological strategies that maximize water-use efficiency without compromising leaf heat resistance properties. These include a reduction in leaf size (Ackerly et al., 2002) and an associated decrease in stomatal conductance; a decrease in cell size and intercellular air spaces (Kummerow, 1973); an increase in mechanical strength (thicker cell walls, more fibrous tissues); and changes in leaf absorbance properties (Aboukhaled, 1966). The ability of a species to tolerate extreme temperature events will be determined by the interaction between leaf heat loads (a function of leaf area and transpiration rate), leaf heatstoring capacity (a function of leaf thickness), and the degree of exposure to environmental elements.

\section{Acknowledgements}

Funds were provided by Curtin University's infrastructure support scheme (via the Australian Research Council). Weather data were provided by Australia's Bureau of Meteorology. The manuscript was written while P. Groom was a research fellow at University of Western Sydney.

\section{Literature cited}

Ackerly, D. D., C. A. Knight, S. Weiss, K. Barton \& K. P. Starmer, 2002. Leaf size, specific leaf area and microhabitat distribution of chaparral woody plants: Contrasting patterns in species level and community level analysis. Oecologia, 130: 449-457.

Aboukhaled, A., 1966. Optical properties of leaves in relation to their energy-balance, photosynthesis, and water use efficiency. Ph.D. thesis, University of California, Davis, California.

Beard, J. S., 1972. Newdegate and Bremer Bay. Vegetation Survey of Western Australia. 1:250 000 series. Vegmap Publications, Applecross, Western Australia.

Beard, J. S., 1984. Biogeography of the kwongan. Pages 1-26 in J. S. Pate \& J. S. Beard (eds.). Kwongan. Plant Life of the Sandplain. University of Western Australia Press, Nedlands, Perth.

Berry, J. \& O. Björkman, 1980. Photosynthetic response and adaptation to temperature in higher plants. Annual Review of Plant Physiology, 31: 491-543.

Bragg, J. G. \& M. Westoby, 2002. Leaf size and foraging for light in a sclerophyll woodland. Functional Ecology, 16: 633-639.

Cody, M. L. \& H. A. Mooney, 1978. Convergence versus nonconvergence in Mediterranean-climate ecosystems. Annual Review of Ecology and Systematics, 9: 265-321.

Faria, T., D. Silvério, E. Breia, R. Cabral, A. Abadia, J. Abadia, J. S. Pereira \& M. M. Chaves, 1998. Differences in the response of carbon assimilation to summer stress (water deficits, high light and temperature) in four Mediterranean tree species. Physiologia Plantarum, 102: 419-428.

Gates, D. M., 1968. Transpiration and leaf temperature. Annual Review of Plant Physiology, 19: 211-238.

George, A. S., 2002. The south-western Australian flora in autumn. Journal of the Royal Society of Western Australia, 85: $1-15$.

Givnish, T. J., 1978. Ecological aspects of plant morphology: Leaf form in relation to environment. Acta Biotheoretica, 27: 83-142.

Gratani, L., P. Pesoli, M. F. Crescente, K. Aichner \& W. Larcher, 2000. Photosynthesis as a temperature indicator in Quercus ilex L. Global and Planetary Change, 24: 153-163.

Groom, P. K., R. H. Froend \& E. M. Mattiske, 2000. Impact of groundwater abstraction on a Banksia woodland, Swan Coastal Plain, Western Australia. Ecological Management and Restoration, 1: 117-124.

Hanba, Y. T., S.-I. Miyazawa \& I. Terashima, 1999. The influence of leaf thickness on the $\mathrm{CO}_{2}$ transfer conductance and leaf stable carbon isotope ratio for some evergreen tree species in Japanese warm-temperate forests. Functional Ecology, 13: 632-639.

Hegazy, A. K. \& M. I. El Amry, 1998. Leaf temperature of sand dune plants: Perspectives on the adaptability of leaf morphology. African Journal of Ecology, 36: 34-43. 
Hobbs, R. J. \& H. A. Mooney, 1995. Effects of episodic rain events on Mediterranean-climate ecosystems. Pages 71-85 in J. Roy, J. Aronson \& F. di Castri (eds.). Time Scales of Biological Responses to Water Constraints. SPB Academic, Amsterdam.

Jones, H. G., 1992. Plants and Microclimate. Cambridge University Press, Cambridge.

Kappen, L., 1981. Ecological significance of resistance to high temperatures. Pages 439-474 in O. L. Lange, P. S. Nobel, C. B. Osmond \& H. Ziegler (eds.). Physiological Plant Ecology I. Responses to the Physical Environment. Encyclopaedia of Plant Physiology. Vol. 12A. Springer-Verlag, Berlin.

Korczynskyj, D., 2002. Phenology and growth of the grasstree Xanthorrhoea preissii in relation to fire and season. Ph.D. thesis, Curtin University of Technology, Perth, Western Australia.

Kummerow, J., 1973. Comparative anatomy of sclerophylls of Mediterranean climate areas. Pages 157-167 in F. di Castri \& H. A. Mooney (eds.). Mediterranean-Type Ecosystems. Springer-Verlag, New York, New York.

Lamont, B. B., P. K. Groom \& R. M. Cowling, 2002. High leaf mass:area of local floras may reflect low rainfall and high water use efficiency rather than low leaf phosphorus and nitrogen content. Functional Ecology, 153: 403-412.

Lange, O. L., J. D. Tenhunen \& M. Braun, 1982. Midday stomatal closure in Mediterranean type sclerophylls under simulated habitat conditions in an environmental chamber. I. Comparison of the behaviour of various European Mediterranean species. Flora, 172: 563-579.

Larcher, W., 2000. Temperature stress and survival ability of Mediterranean sclerophyllous plants. Plant Biosystems, 134: 279-295.

MacBryde, B., R. L. Jefferies, R. Alderfer \& D. M. Gates, 1971. Water and energy relations of plant leaves during period of heat stress. Oecologica Plantarum, 6: 151-162.

Miller, P. C., 1983. Canopy structure of Mediterranean-type shrubs in relation to heat and moisture. Pages 133-166 in F. J. Kruger, D. T. Mitchell \& J. U. M. Jarvis (eds.). Mediterranean-Type Ecosystems. The Role of Nutrients. Springer-Verlag, Berlin.

Mooney, H. A. \& E. L. Dunn, 1970. Convergent evolution of Mediterranean-climate evergreen sclerophyll shrubs. Evolution, 24: 292-303.

Nahal, I., 1981. The Mediterranean climate from a biological viewpoint. Pages 63-93 in F. di Castri, D. W. Goodall \& R. L. Specht (eds.). Mediterranean-Type Shrublands. Ecosystems of the World. Vol. 11. Elsevier Scientific, Amsterdam.

Niinemets, Ü., 1999. Components of leaf dry mass per area thickness and density - alter leaf photosynthetic capacity in reverse directions in woody plants. New Phytologist, 144: 35-47.

Niinemets, Ü., 2001. Global-scale climatic controls of leaf dry mass per area, density, and thickness in trees and shrubs. Ecology, 82: 453-469.

Nobel, P. S., 1988. Principles underlying the prediction of temperature in plants, with special reference to desert succulents. Pages 1-23 in S. P. Long \& F. I. Woodward (eds.). Plants and Temperature. The Company of Biologists, Cambridge.

Oechel, W. C., W. Lawrence, J. Mustafa \& J. Martínez, 1981. Energy and carbon acquisition. Pages 151-183 in P. C. Miller (ed.). Resource Use by Chaparral and Matorral. Springer-Verlag, New York, New York.
Oertli, J. J., S. H. Lips \& M. Agami, 1990. The strength of sclerophyllous cells to resist collapse due to negative turgor pressure. Acta Oecologica, 11: 281-289.

Paczkowska, G. \& A. R. Chapman, 2000. The Western Australian Flora. Wildflower Society of Western Australia, Nedlands.

Peñuelas, J., F. Lloret \& R. Montoya, 2001. Severe drought effects on Mediterranean woody flora in Spain. Forest Science, 47: 214-218.

Pereira, J. S. \& M. M. Chaves, 1995. Plant responses to drought under climate change in Mediterranean-type ecosystems. Pages 140-160 in J. M. Moreno \& W. C. Oechel (eds.). Global Change and Mediterranean-type Ecosystems. Springer-Verlag, New York, New York.

Podani, J., 1995. SYN-TAX 5.02. Mac Users Guide. Scientia Publishing, Budapest.

Roderick, M. L., S. L. Berry \& I. R. Noble, 2000. A framework for understanding the relationship between environment and vegetation based on the surface area to volume ratio of leaves. Functional Ecology, 14: 423-437.

Roderick, M. L., S. L. Berry, I. R. Noble \& G. D. Farquhar, 1999. A theoretical approach to linking the composition and morphology with the function of leaves. Functional Ecology, 13: 683-695.

Shearer, B. L., R. G. Fairman \& J. A. Bathgate, 1995. Cryptodiaporthe melanocraspeda canker as a threat to Banksia coccinea on the south coast of Western Australia. Plant Disease, 79: 637-641.

Smith, W. K., D. T. Bell \& K. A. Shepherd, 1998. Associations between leaf structure, orientation, and sunlight exposure in five Western Australian communities. American Journal of Botany, 85: 56-63.

Smith, W. K. \& P. S. Nobel, 1978. Influence of irradiation, soil water potential, and leaf temperature on leaf morphology of a desert broadleaf, Encelia farinose Gray (Compositae). American Journal of Botany, 65: 429-432.

Terashima, I., S.-I. Miyazawa \& Y. T. Hanba, 2001 Why are sun leaves thicker than shade leaves? Consideration based on analyses of $\mathrm{CO}_{2}$ diffusion in the leaf. Journal of Plant Research, 114: 93-105.

Turner, I. M., 1994. Sclerophylly: Primarily protective? Functional Ecology, 8: 669-675.

Valladares, F. \& R. W. Pearcy, 1997. Interactions between water stress, sun-shade acclimation, heat tolerance and photoinhibition in the sclerophyll Heteromeles arbutifolia. Plant, Cell and Environment, 20: 25-36.

Valladares, F. \& R. W. Pearcy, 1999. The geometry of light interception by shoots of Heteromeles arbutifolia: Morphological and physiological consequences for individual leaves. Oecologia, 121: 171-182.

Vogel, S., 1968. Sun leaves and shade leaves: Differences in convective heat dissipation. Ecology, 49: 1203-1204.

Witkowski, E. T. F. \& B. B. Lamont, 1991. Leaf specific mass confounds leaf density and thickness. Oecologia, 88: 486-493.

Yun, J. I. \& S. E. Taylor, 1986. Adaptive implications of leaf thickness for sun and shade-grown Abutilon theophrasti. Ecology, 67: 1314-1318.

Zohar, Y., Y. Waisel \& R. Karschon, 1981. Heat and cold resistance of Eucalyptus occidentalis Endl. leaves and its relationship to soil water conditions. Australian Journal of Ecology, 6: 79-84. 